\title{
Research on Talent Training Mode of Port, Waterway and Coastal Engineering Based on Engineering Education Professional Certification
}

\author{
Chao Wan ${ }^{1}$ Feng Jin ${ }^{2, *}$ Hong Wang ${ }^{2}$ \\ ${ }^{1}$ School of Energy and Power, Jiangsu University of Science and Technology, Zhenjiang, P. R. China \\ ${ }^{2}$ School of Naval Architecture and Ocean Engineering, Jiangsu University of Science and Technology, Zhenjiang, P. \\ R. China \\ ${ }^{*}$ Corresponding author. Email: jflook@126.com
}

\begin{abstract}
Professional evaluation and certification is an important means to ensure the quality of higher education in the world, China's engineering education quality assurance system has been internationally recognized. With the continuous advancement of engineering education professional certification, in order to adapt to the development situation of higher education, combined with the needs of new engineering construction, taking engineering education professional certification as an opportunity to carry out professional personnel training reform is of great significance to improve the quality of personnel training. In recent years, in the process of specialty construction, around the concept of "student-centred, learning achievement oriented, ability training as the core", we reconstruct the talent training mode, optimize the curriculum system, improve the quality evaluation mechanism, and explore the practice for improving the quality of talent training.
\end{abstract}

Keywords: Engineering Education, Professional Certification, Training Mode, Curriculum System, Quality Evaluation

\section{RESEARCH ON THE TRAINING MODE}

Under the guidance of certain modern education theories and ideas, talent training mode is the sum of the process of implementing talent education with relatively stable teaching content and curriculum system, management system and evaluation method according to specific training objectives and talent specifications[1]. The construction of talent training mode belongs to internal reform, and the basic requirement of engineering education professional certification as the implementation of talent training process belongs to external evaluation. Professional certification attaches importance to the results, and the construction of the mode emphasizes the process. The difference between the two reflects a complementary effect, that is, the construction of the model can be viewed by the authentication method, and the requirements of the construction mode can also be regarded as the "evidence" in professional certification. The organic combination of the two will further improve students' engineering ability and social recognition.

According to the needs of science and technology and social and economic development, based on the concept of engineering education professional certification, combined with the professional talent training orientation, the port, waterway and coastal engineering specialty formulates the talent training objectives covering talent types, service fields, professional characteristics and ability potential Systematically sort out the knowledge structure, ability and quality that should be possessed to achieve the training objectives; formulate the graduation requirements that are oriented, measurable and reflect the professional characteristics; implement the main line of students' ability training, design the professional curriculum system and maintain continuous improvement [2]. The design process is shown in Figure 1.

Talent training mode usually has four meanings: defined training objectives and specifications, complete 
education process to achieve the objectives and specifications, management and evaluation system formed around the education process, scientific education methods and teaching means $[3,4]$. The talent training mode of this major aims at the coordinated development of students' knowledge, ability and quality, closely around the goal of cultivating applied senior professionals with innovative spirit and practical ability in this industry, so as to integrate majors, courses, teaching materials, teaching methods and evaluation system.

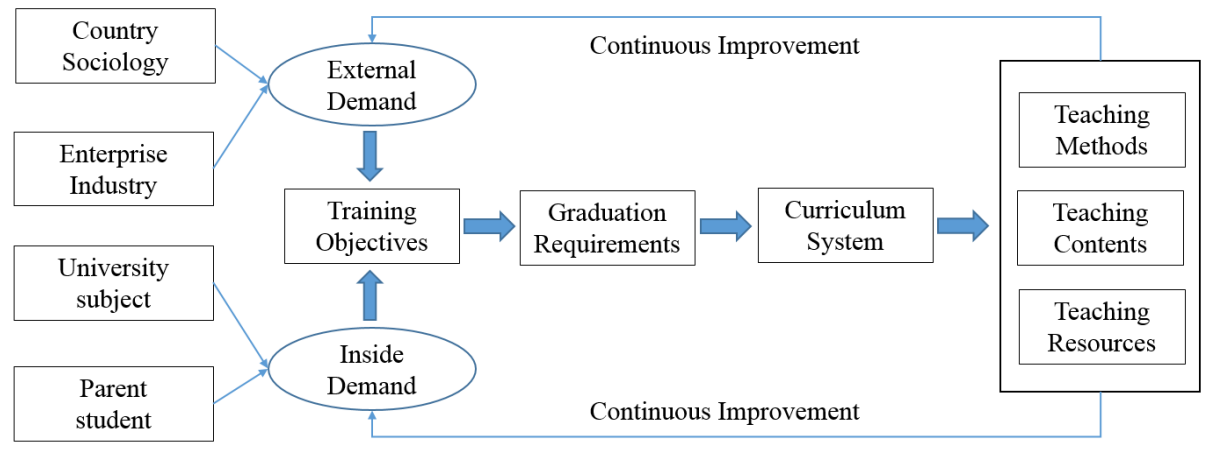

Figure 1 Design process

\section{CONSTRUCTING CURRICULUM SYSTEM}

According to the professional training objectives, we should scientifically build the basic platform of general education and discipline, sort out the main professional courses, flexibly set the direction of major, strengthen the engineering practice ability, and cultivate the team cooperation and innovation spirit. On this basis, the five integration of teaching mode are realized, namely, general education and professional education, theoretical teaching and practical teaching, science education and humanities education, quality education and innovation education, discipline construction and undergraduate teaching [2].

\subsection{Theoretical curriculum system}

This major closely tracks the development of the industry, and invites domestic well-known enterprises and senior scholars to participate in the formulation of talent training programs. Taking the training of advanced engineering technology and engineering management talents with advanced professional technology, outstanding engineering ability and excellent engineering quality as the training goal, a school enterprise joint training system integrating knowledge structure and quality ability training is constructed.

The system consists of three training platforms: General Education Foundation, basic education of major disciplines, professional education and engineering practice education. Each platform is composed of three training modules: theoretical curriculum module, school practice module and enterprise learning and practice module. Each module focuses on the training of "four engineering abilities", namely basic engineering quality and ability, engineering design ability, project implementation and engineering management ability, comprehensive practice and innovation ability. The research establishes five professional core knowledge areas, including engineering mechanics, engineering graphics, engineering design, engineering construction and engineering management. The teaching contents include general basic course group, professional basic course group, special course group, engineering application course, ability development course and enterprise project practice. Students can systematically learn the knowledge of professional field in exploration, research and practice, and their engineering practice ability, project management ability and innovation ability are gradually improved $[5,6]$. The curriculum system is shown in Figure 2.

\subsection{Practice curriculum system}

The major actively promotes the reform of practice teaching system, and jointly constructs the practice teaching system based on "three training modules" with well-known enterprises in the industry, highlighting the cultivation of "four engineering abilities". Among them, the new "engineering software training and practice", "BIM design and construction technology" and other practical courses are set up to meet the technical needs of enterprises. Optimize the practical teaching content, and form the curriculum design group of engineering design, engineering construction and engineering management according to the professional characteristics. Using and expanding teaching resources, setting up comprehensive and designing experiments, cultivating students' scientific thinking and innovation ability. The training system of engineering design ability and innovation ability is shown in Figure 3. 



\begin{tabular}{|c|c|c|c|c|c|c|}
\hline $\begin{array}{c}\text { Basic Engineering } \\
\text { Capability }\end{array}$ & $\Longleftrightarrow$ & $\begin{array}{c}\text { Engineering Design } \\
\text { Capability }\end{array}$ & $\Longleftrightarrow$ & $\begin{array}{c}\text { Construction Management } \\
\text { Capability }\end{array}$ & $\Longleftrightarrow$ & $\begin{array}{c}\text { Practice Innovation } \\
\text { Capability }\end{array}$ \\
\hline
\end{tabular}



Figure 3 Training system of engineering design ability and innovation ability

Relying on the engineering practice centre on campus, the professional backbone courses focus on the teaching mode of "combining teaching content with enterprise projects, solving engineering problems through classroom teaching", and strengthen the cultivation of students' practical ability. For example, the projects of China Communications 2nd Navigational bureau 3rd Engineering Co.,Ltd and Zhenjiang port company are introduced into the teaching of professional courses. In addition, the teaching and training of software such as soil mechanics calculation, engineering project budget, engineering project management and structural calculation are also provided for students, so as to realize the curriculum system of combining theory with practice and cooperating between universities and enterprises.

\section{QUALITY EVALUATION MECHANISM}

\subsection{Quality control mechanism of teaching process}

In order to ensure the quality of personnel training, appropriate quality management should be carried out for each teaching link. Teaching links have clear implementation contents, objectives and assessment requirements, forming an orderly and standardized routine teaching management mode. According to the development demand, the major has implemented and improved the curriculum group system in recent years. The head of the curriculum group organizes the regular teaching research and training, plans and determines the implementation plan for the course development, coordinates and arranges the teaching tasks of the 
course, collects the feedback teaching problems, discusses and forms the improvement measures. By perfecting the system of curriculum group, implementing the management of the person in charge of the curriculum group, and taking the curriculum as the center, the new mode of collaborative teaching, unified construction and centralized supervision is formed. After the implementation of the curriculum group system, the distribution of teaching tasks is adjusted dynamically, and teachers compete for posts according to the teaching quality. In addition, the teaching performance assessment is carried out in the whole school, facing all full-time teachers, monitoring the teaching links throughout the process, assessing the teaching performance of teachers, rewarding excellent model teachers, so that teachers can be reassured and improve the quality of education.

\subsection{Evaluation mechanism of training quality}

The evaluation mechanism of students' training quality includes course evaluation and graduation evaluation. The former mainly reflects the evaluation of course teaching effect and provides basic data for graduation evaluation. The latter mainly reflects the overall ability level of students and reflects the final result of training quality. Combined with the characteristics of the course, this major integrates engineering problems into the teaching content, guides students to analyse problems in the teaching design and implementation, and continuously trains students' ability to solve engineering problems by using engineering knowledge and general software. In the course evaluation, it puts forward the requirements of literature review and research, principle analysis and application, communication and cooperation and division of labour, international vision and innovation consciousness, so as to provide strong support for the comprehensive evaluation of talent training quality. Graduation evaluation is based on systematic data, the use of scientific evaluation methods, the formation of a detailed evaluation report, combined with professional third-party comprehensive evaluation, a more comprehensive reflection of the quality of graduate training.

\section{GUARANTEE OF TEACHING STAFF}

In order to meet the needs of personnel training, we should provide sufficient teachers for protection. First of all, we should strengthen the construction of the existing teaching team, unify the teaching expertise in the Curriculum Center, combine with the direction of scientific research to create professional characteristics, and form the dual drive of talent cultivation on the basis of a stable teaching and scientific research team. Secondly, expand the channels for talent introduction and provide flexible working forms. For high-level talents, flexible Introduction and appointment can be carried out. For enterprises and institutions with sufficient engineering experience, they can participate in practical teaching as part-time teachers. Thirdly, through fruitful cooperation with the industry, in-depth participation of teachers and on-site training of students, it not only solves the problems of front-line guidance and site, but also promotes the transformation of scientific research content to teaching and the transformation of scientific research achievements to teaching achievements.

Focusing on the construction objectives, this major has formulated a feasible plan for the construction of the teaching staff, continuously optimized the structure and level of the teaching staff, and significantly improved the overall strength compared with that before passing the engineering education certification. In the past three years, teachers of this major have undertaken 2 provincial and above scientific research fund projects, 4 Municipal Fund projects, and a number of enterprise cooperative R \& D projects; obtained 6 invention patents and software copyrights, published nearly 30 academic papers of various types, including nearly 10 papers collected by international search institutions (SCI, EI); teachers guide students to carry out innovation and entrepreneurship projects and get many awards from national science and technology competitions, and they won awards in the national youth teachers lecture competition. The improvement of teachers' teaching and scientific research level effectively feeds back on teaching and provides a strong guarantee for the achievement of teaching objectives and personnel training objectives.

\section{CONCLUSION}

The major of port, waterway and coastal engineering follows the basic law of personnel training, combines with the development trend of higher education, centres on the requirements of engineering education certification and new engineering construction, and under the guidance of the professional teaching steering committee of the Ministry of education, scientifically constructs the personnel training mode. By reforming the theoretical teaching system, establishing a diversified practical teaching system, updating the teaching content and methods, improving the training quality evaluation mechanism, strengthening the guarantee of the teaching staff, the professional construction and the quality of talent training have been steadily improved. In 2020, this major was rated as a characteristic major of Jiangsu Province, and in 2019, it successfully passed the re-examination of engineering education professional certification, and once again won the international mutual recognition of engineering education and engineer qualification. In the future, this major will continue to adhere to the road of 
characteristic development and connotation development, and cultivate higher quality applied senior professionals for economic and social construction and national rejuvenation.

\section{REFERENCES}

[1] Li Jixing. From the knowledge system to the ability system, the reform of personnel training mode and the cultivation of innovative talents $[\mathrm{J}]$. People's Education,2011(23):8-11.

[2] Yin Qun, Zhu Yazhou, Wang Yue, Chen Shulin. Majoring in Naval Architecture and Ocean Engineering in application oriented universities based on new engineering concept, Research on the construction of talent training program $[\mathrm{J}]$. Education Modernization,2019,6(86):8-10.

[3] Chen Liping. Research on Construction of Cultivation Mode of 2L3I Type Bilingual Talents in Higher Vocational Education Colleges [J]. Journal of Tianjin Vocational Institutes,2020,22(11):60-64.

[4] Zhou Lanfeng. Research on talent training mode of newly established local universities in Fujian Province -- Taking Putian University as an example [J]. Journal of Hubei University of Economics (HUMANITIES AND SOCIAL SCIENCES EDITION), 2012,9 (06): 170-171.

[5] Ying Qin, Zhong Liang. Discussion on the implementation plan of "Excellent Mechanical Engineer" training $[\mathrm{J}]$. Science \& Technology Information,2012(16):248.

[6] Ji Chunyan, Li Liangbi. On the Excellent Engineers Cultivating Plan for the Speciality of Ocean Engineering and Technology [j]. Ship sea engineering, 2012,41 (06): 108-111+115. 